\title{
GUERRA CIVIL EN NUEVA ESPAÑA (1810-1815)
}

Las tierras de Nueva España, tan pródigas en riquezas naturales, aparecían esquilmadas y empobrecidas en la segunda década del siglo XIX, no sólo por los inconvenientes del sistema económico colonial español, sino, sobre todo, por los rigores de una guerra que durante varios años lo llevó todo a sangre y fuego.

\section{LAS CAUSAS DE LA INSURRECCIÓN: EL PROCESO \\ QUE CONDUCE A LA INDEPENDENCIA, VISTO COMO GUERRA CIVIL}

\section{Algunas interpretaciones de la independencia. Opiniones de contemporáneos de los bechos ${ }^{1}$}

Pudo parecer que Nueva España resultaría menos afectada que otros territorios americanos por las desalentadoras noticias de Europa en 1810, habida cuenta del control que los peninsulares ejercían sobre la burocracia tras los acontecimientos de septiembre

1 Así resumía el profesor Navarro García las principales líneas de interpretación de la independencia, en un encuentro de historiadores de Américá que se celebró en 1988: a)Teoría de la conspiración internacional, que enfatiza la inter vención británica y el influjo de la masonería; b) teoría de la influencia de las revoluciones norteamericana y francesa; c) teoría de la madurez o de la mayería de edad de las colonias; d) teoría del odio de razas; e) teoría de la crisis política de la monarquía española, scausada por la invasión napoleónica y la ruptura del pacto social, agravada por el inopinado e intermitente ensayo del liberalismo peninsular»; $f$ ) teoría de la resistencia de las colonias frente al creciente despotismo borbónico o Prente al liberalismo (cfr. Navarro García, L.: La Independencia de Hispanoamérica, en Vázquez de Prada, V. y Olabarri Gortázar, I. (eds.): Balance de la Historiografía sobre Iberoamérica. Actas de las IV Conversaciontes Internacionales de Historia. Pamplona, 1989, págs. 531-534). Como el mismo autor señala, estas dos últimas interpretaciones «constituyen el núcleo del enfoque más reciente, fruto de la amplia y bastante desapasionada investigación desarrollada en los últimos años y que ha relegado al olvido la mayoría de los tópicos repetidos durante más de un siglo». En ese contexto se insertan los trabajos de Giménez Fernández, 
de 1808 que acarrearon la deposición del virrey Iturrigaray. ${ }^{2} \mathrm{La}$ realidad vino a demostrar lo equivocado de tales supuestos: así, los representantes de Nueva España en las Cortes de Cádiz resultaron ser más adictos a la causa insurgente que fieles al gobierno español, hasta el punto de ofrecerse algunos de ellos a Morelos a través de sus enlaces en México para ejercer sus funciones en el Congreso que aquél presidía. ${ }^{3}$

Tanzi o Stoetzer, que insisten en la trascendencia que se ha de conceder a la teoría escolástica del «pactum translationis», que concedía al pueblo el derecho a darse un nuevo gobierno cuando, por las razones que fueren, hubiese cesado el anterior. «Aunque conocida en Indias, nadie necesitaba esgrimir la teoría rusoniana sobre el particular, que por otra parte no era sino una reelaboración del pensamiento escolástico (Navarro García, L.: La Independencia de Hispanoamérica, pág. 541). Brading, por su parte, ha destacado la posible influencia de las doctrinas de Puffendorf $\mathrm{y}$ de Heineccius en las actuaciones del ayuntamiento de México durante la critica coyuntura de 1808 (cfr. Brading. D. A.: The Origins of Mexican Nationalism, Cambridge, 1985, págs. 43-44). Unas páginas muy sugerentes sobre el carácter de la revolución de la América española, en Stoetzer, O. C.: El pensamiento político en la América española durante el periodo de la emancipación (1789-1825). Las bases hispánicas y las corrientes europeas. 2 vols. Madrid, 1966. tomo I, págs. 87-98. El mismo autor ha vuelto a ocuparse de esta cuestión en Las raíces escolásticas de la Emancipación española, Madrid, 1982.

2 Por razones de espacio no podemos entretenernos en las circunstancias que condujeron a la sustitución de Iturrigaray en el mando del virreinato. Un estudio muv documentado. que puede consultarse, es el de Lafuente Ferrari. E.: El virrey Iturrigaray y los orínenes de la independencia de Méjico, Madrid, 1941. También se trata de la deposición de este virrey en un trabajo, inspirado en buena parte en el de Lafuente: Real Díaz, J. J. y Heredia Herrera, A. M.: «El Virrey don José de Iturrigaray,» en la obra colectiva, dirigida por Calderón Quijano, J. A.: Los Virreyes de Nueva España en el reinado de Carlos IV. 2 vols.. Sevilla, 1972, tomo II, págs. 183-331 (más concretamente, págs. 318-323). Además puede interesar Anna, T. E.: The Fall of the Royal Government in Mexico City, Lincoln, 1978, págs. 41-51, y las referencias que aparecen en Valle Arizpe, A. de: Virreyes y virreinas de Nueva España, 2 vols. Madrid, 1933, tomo II, págs. 295 y sigs. Algunas notas sobre la presencia de peninsulares en cargos de la administración pública, la Iglesia, la magistratura y el ejército, en Flores Caballero, R.: La contrarrevolu ción en la independencia. Los españoles en la vida politica, social y económica de México, 1804-1838. México, 1969, págs. 22-27. Un buen análisis del vacío de poder creado en Nueva España por la invasión francesa, y de los debates en el seno de la audiencia y el cabildo, en Anna, T. E.: \&The Independence of Mexico and Central America», en Bethell, L. (ed.): The Cambridge History of Latin America. Cambridge, 1985, tomo III, págs. 58-60.

3 Archivo General de Indias (A.G.I.), México, 1.482. Carta de Número 12 (nombre en clave de un agente rebelde) a Morelos, 21 de noviembre de 1813. Este escrito aparece incluido en el cuaderno 4 de la carta núm. 15 del virrey Calleja al ministro de Gobernación de Ultramar. México, 31 de octubre de 1814. Casi toda la correspondencia de los rebeldes que se cita proviene de los anejos a esta carta, por lo que desde ahora indicaremos sólo el cuaderno a que corresponde cada documento. También Berruezo destaca la decidida inclinación por la independencia 
En las provincias, sobre todo en los distritos mineros del norte y oeste de México, la autoridad peninsular era débil; y los agentes de Bonaparte, que operaban desde Baltimore y Nueva Orleans, encontraron un ambiente propicio para fomentar la subversión. Los preparativos insurreccionales se multiplicaban por doquier: en 1809 se organizó en Valladolid un movimiento revolucionario, que fue descubierto y desarticulado. Un año después, un grupo de criollos se reunía en Querétaro y trataba sobre el modo de expulsar a los españoles de la capital del virreinato; su plan, muy avanzado, fue desbaratado en última instancia. En la mañana del 16 de septiembre de 1810 , el cura Hidalgo convocaba a los vecinos de Dolores para exhortarles a que se declararan por la independencia, paradójicamente, en nombre de Fernando VII. ${ }^{4}$

El obispo de Valladolid (Michoacán), Abad y Queipo, ${ }^{5}$ es autor de una sustanciosa carta a Lardizábal y Uribe, ${ }^{6}$ cuyo contenido arroja luz sobre lo que pensaban algunos contemporáneos que constituía el trasfondo de los acontecimientos.

de su país de parte de la representación mexicana en las Cortes de Cádiz. Berruezo, M. T.: La participación americana en las Cortes de Cádiz (1810-1814). Madrin!, 1986, pág. 104.

4 Fagg. J. E.: Historia general de Latinoamérica. Madrid, 1970, págs. 484-485.

5 Don Manuel Abad y Queipo, asturiano, se trasladó a América a los veintiocho años y fue un «celoso defensor de los derechos de la Iglesia y del bienestar de su clero y pueblo, reformista y avanzado, no lejano del ideario insurgente, pero leal al rey, enemigo del separatismo, malquisto al fln por ambos bandos, nombrado ministro por Fernando VII y procesado por la Inquisición at día siguiente». Se deben a su pluma interesantes reflexiones sobre la situación moral, social y política de Nueva España entre 1799 y 1810 (cfr. Ezquerra, R. de: «La crítica española sobre América en el siglo XVIII», en Estudios sobre la Eman cipación de Hispanoamérica. Contribución al Sesquicentenario de la Emancipación. * Madrid, 1963, págs. 393-396). Otros datos biográflcos de Abad y Queipo, en Morales, F.: Clero y política en México, 1767-1834. México, 1975, págs. 49-54, y Fisher, L. E.: Champion of Reform, Abad y Queipo, New York, 1955.

6 Don Miguel de Lardiábal y Uribe, natural de Tlaxcala, había sido designado diputado de Nueva España y vocal de la Junta Central en octubre de 1809, en conformidad con el decreto de 22 de enero de ese año. Después de la disolución de la Junta Central y de la formación de la Regencia -enero de 1810 Lardizábal pasó a ser el representante americano en el nuevo órgano de gobierno (cfr. Miranda, J.: Las ideas y las instituciones políticas mexicanas, México, 1978, págs. 226-2¿8, y Zárate Toscano, V.: El testamento político de los diputados americanos en 1814. «Anuario de Estudios Americanos». XLV. Sevilla, 1988, págs. 343-345). En 1814, era ministro de Gobernación de Ultramar. Otras notas biográficas sobre Lardizábal, en Berruezo, M. T.: La participación americana..., págs. 34-36. 
Se refería en ese escrito a la circular de Lardizábal del 24 de mayo de 1814, en la que atribuía la guerra a la rivalidad entre gachupines ${ }^{7}$ y criollos. De ese parecer discrepaba Abad y Queipo: la guerra no era - como venía sosteniéndose- consecuencia de una lucha de hermanos entre sí; más bien había de buscarse la verdadera causa en el deseo de independencia y separación de la metrópoli, arraigado en unos cuantos que lo propagaron persuadidos de que la pérdida de España era irreparable:

(no es ésta, pues, una diferencia entre hermanos, causada por la ausencia del Padre común; sino una conspiración infame y atroz de los hijos contra su Padre y su Madre, contra su Rey y su Patria, con el fin de ocupar el mando y el patrimonio común».. ${ }^{8}$

Don José Mariano Beristain, canónigo y decano del cabildo catedralicio de México, por su parte, opinaba que faltaba en la corte un conocimiento exacto de lo que ocurría en Nueva España. En noviembre de 1814, cansado y abrumado por la vejez y los

7 El término gachupín designaba a los españoles nacidos en la península. La contraposición entre gachupines y criollos ha sido para muchos historiadores -empezando por Alamán- la principal causa de la revolución. Anna, partiendo de los trabajos de Brading. D. A.: Miners and Merchants in Bourbon Mexico. 1763-1810. Cambridge, 1971, y Ladd, D. M.: La nobleza mexicana en la época de la Independencia 1780-1826. México, 1984, ha revisado esa tesis, que -aunque no carente de fundamento resulta demasiado simplista porque, entre otros motivos. no presta atención al hecho de que los sectores más relevantes de ambos grupos sostenian muy estrechas relaciones por motivos de parentesco (cfr. Anna, T. E.: The Fall of the Royal Government in Mexico City, págs. 9 y 20, y The Independence of Mexico, pág. 54). El mismo Anna, al rectiffcar ese punto de vista, se: inclina por la interpretación propuesta por Luis Villoro: El proceso ideológico de la revolución de independencia. México, 1981: athe place of birth was less important in determining the political objectives of various groups in New Spain than class, income, associations, and kinship and compadrazgo loyalties» (Anna, T. E.: The Fall of the Royal Government in Mexico City, págs. 9-10). De todos modos, aunque las observaciones de Villoro hayan contribuido a un enfoque más realista, su cansina insistencia en ela clase agraviada» o ela clase ofensora y su acento casi exclusivo en la vertiente social del conflicto restan credibilidad a sus explicaciones. Por último, Hamnett concede mucha importancia a las divisiones que existían entre los propios peninsulares, principalmente por motivos económicos y administrativos. Hamnett, B. R.: Mexico's Royalist Coalition: The Rlesponse to Revolution, 1808-1821, en «Journal of Latin American Studies», 12:1. Oxford, mayo 1980, pág. 57.

8 A.G.I., Estado, 41, ramo 46. Carta de Abad y Queipo a don Miguel de Lardizábal y Uribe. Valladolid, 1 octubre 1814. 
ataques de sus enemigos — tenía ya sesenta años-, pedía que se le relevara del decanato de México:

"Yo no puedo vivir aquí. He trabajado muchos [años] en dos sedes vacantes, y en tiempos dificilísimos: y en veinte años no se ha puesto Carta, Representación, Edicto, Decreto, Pastoral, Informe para el Cabildo de México en sede plena, o vacante que no haya sido obra mía. Más: el año pasado pasé a Querétaro, que iba a perderse, con el título de Visitador extraordinario, nombrado por el Virrey actual [don Félix María Calleja del Rey] y por el Arzobispo Gobernador, estuve ocho meses, gasté mucho dinero mío, y dejé aquella ciudad como un mar de leches. ${ }^{9}$

Tras esta exposición de sus servicios a la patria, el canónigo solicitaba que se le enviase a alguna región española de clima benigno, para reponer su salud, sin que dejara de emitir un juicio sobre las causas de la guerra, que no atribuía a agravios inferidos o a quejas más o menos fundadas, sino a los deseos de independencia absoluta de los sectores más ilustrados del país.

Al decir de Beristain, gentes feroces y desenfrenadas, instigadas por aquellos grupos intelectuales, componían las partidas que asolaban el reino y destruían pueblos, haciendas, minas y fábricas aplicando la máxima que aprendieron de Napoleón: «el pueblo que quiere ser libre, lo consigue». Para ello no vacilaban en destruir las fuentes de riqueza del gobierno, en un criminal intento de provocar su colapso. ${ }^{10}$ Beristain, al igual que Abad y Queipo, insistía en que los políticos españoles desconocían la realidad americana.

No eran éstas la únicas razones que se adujeron para explicar el desencadenamiento de la guerra. Lafaye deduce de la lectura de

9 A.G.I., Estado, 42, ramo 19. México, 28 de noviembre de 1814. La figura de Beristain, uno de los más inteligentes partidarios de la Corona, ha sido objeto de varios estudios, entre los que pueden citarse Fuentes de la historia contemporánea de México, Libros y folletos, 2 tomos, México, 1961, págs. XXIV-XXVII, y" Medina, J. T.: Don José Mariano Beristain de Sousa. Estudio bio-bibliográfica. Santiago de Chile, 1897.

10 A.G.I., Estado, 42, ramo 19. Carta de don José Mariano Beristain. México, 28 de noviembre de 1814. 
la carta secreta que el 22 de enero de 1812 dirigió el virrey Venegas al ministro de Gracia y Justicia que el odio al gachupín era, para la mayoría de los partidarios de la independencia, el principal resorte pasional. Tal vez este sentimiento, al racionalizarse, podía explicar los anhelos de independencia en que tanto insistía el obispo de Valladolid. Los principios de la Revolución Francesa pudieron interesar tan sólo a un pequeño número de ideólogos que, como Cos, componían la independentista Junta dirigente. Existiendo, es innegable, una influencia de la ideología francesa revolucionaria, debe insistirse especialmente en el sentimiento antigachupín, tan vivo en Nueva España. ${ }^{11}$

Cómo explicar, si se prescinde de este estímulo, o al menos si se le margina a un segundo plano, el anhelo de ruptura de los vínculos que unían a Nueva España con la metrópoli? Para responder a este interrogante sería preciso plantear en sus justos términos la influencia del racionalismo en el mundo hispánico durante los siglos XVIII y XIX: después del trabajo de Sarrailh sobre La España ilustrada, se hace esperar la aparición de un libro que llevase el título de La España tradicionalista: el fenómeno de las luces, como ha mostrado Sarrailh, minoritario y limitado en las posesiones de la corona de España, no cobrará su plena significación mientras no se le inserte en un estudio más amplio acerca del inmovilismo y de las resistencias con que tropezó el espíritu filosófico. ${ }^{12}$

La secesión espiritual de Nueva España, que precede casi en medio siglo a la disidencia política, había hecho aparecer a la metrópoli en vías de reforma bajo el impulso de Carlos III, como un país innovador, fuertemente contrastado con el conservador virreinato, defensor de los jesuitas expulsados de España por los déspotas ilustrados. Esto es lo que llevaba a reclamar la unión de los americanos con objeto de obtener la independencia y «conservar» así la América española pese a la traición de los europeos, acusados de actuar al servicio de Napoleón. Los gachupines habrían

11 Lafaye, J.: Une liste d'écrits séditieux saisis au Mexique en 1812. París, 1966, pág. 8.

12 Ibídem, págs. 13-14. 
traicionado la causa secular dejando penetrar en la península, primero, las ideas de la Ilustración; luego, a los agentes de $\mathrm{Na}$ poleón $\mathrm{y}$, por fin, como coronamiento, a José Bonaparte. ${ }^{13}$

Los enemigos de los gachupines no tenían por qué ser forzosamente indios, ni pertenecer a ninguna de las castas: es inútil y desenfocado buscar una explicación que se inspire en odios o resentimientos raciales. Malagón señala a este respecto una característica común al Nuevo Mundo con la única excepción de Haití: la independencia fundamental con respecto a los movimientos de signo independentista que se desarrollarían en los países africanos y asiáticos en la siguiente centuria, ya que en todos éstos prevalecería siempre una acusada fobia al «hombre blanco». ${ }^{14}$

En otras palabras, los representantes de la cultura occidental, en nuestro caso de la española, fueron los que se separaron del gobierno europeo, para continuar en ciertos aspectos una vida independiente, que mantenía casi en su totalidad la propia organización anterior a la ruptura.

Busquemos de nuevo la interpretación de otro contemporáneo de los hechos: en este caso, don Antonio Joaquín Pérez, que había sido diputado por la provincia de Puebla. ${ }^{15}$ Un informe suyo al duque de San Carlos contenía una primera parte, que titulaba La revolución en Nueva España, en la que refería los sentimientos

13 Ibidem, pág. 10.

14 Cfr. Malagón Barceló, J.: La influencia del derecho español en HispanoAmérica, en «Anuario de Éstudios Americanos», tomo XXIV, Sevilla, 1967, páginas $1.807-1.819$.

15 Don Antonio Joaquín Pérez desempeñó un papel muy activo en las críticas fechas de mayo de 1814, con ocasión del regreso a la península de Fernando VII. Como representante de Nueva Lspaña presentó al Rey una petición firmada por él y por otros sesenta y ocho diputados, en la que se recomendaba al monarca que disolviera las Cortes y recuperara su poder absoluto. Su acomodación a los nuevos tiempos se refleja en el nombramiento de obispo de Puebla que no iardaría en recaer en su persona. Desde entonces se distinguiría por su honda rivalidad con el virrey Calleja, a cuya caída contribuyó decisivamente. La habilidad y el oportunismo de Pérez se pusieron de manifiesto años después, al decantarse en favor de la independencia de México. y asegurarse así un lugar de preeminencia en ell nuevo orden politico. Macaulay, N.: «The Army of New Spain and the Mexican Dellegalion to the Spanish Cortes», en Benson, N. L. (ed.): Mexico and the Spanish Cortes, 1810-1822. Austin-London, 1956, págs. 135, 145-146. Un balance de sus intervenciones en las Cortes y de su trayectoria política, en Berruezo, M. T.: La participación americana..., págs. 83-88. 
favorables con que se acogió en el virreinato la exaltación de Fernando VII al trono en el mes de mayo de 1808.

Las noticias recibidas en julio sobre la salida del rey a Bayona y la ocupación de la península por las tropas de Murat corroboraron la fidelidad de los habitantes de Nueva España, que seguían con ansiedad la suerte de las tropas españolas. Sin embargo, ya en septiembre de aquel año se registraron en México algunas convulsiones, a las que dio ocasión el virrey Iturrigaray cuando, cediendo a presiones, decidió formar una Junta. Acabó este suceso con la deposición del virrey y el traspaso del mando militar y político a don Pedro Garibay, al que sucedió la Audiencia hasta que en febrero de 1809 fue nombrado virrey Lizana y Beaumont, arzobispo de México, que no tardaría en ser relevado, en mayo de 1810, por don Francisco Javier Venegas. ${ }^{16}$ En apreciación de Pérez, estos acontecimientos no afectaron a la fidelidad del pueblo, cuyo único descontento venía motivado por la venalidad de algunos funcionarios de la administración.

Pasaba luego a narrar la revolución de Hidalgo, que estalló cuando Pérez se disponía a embarcarse para España, en su calidad de diputado: junto a los indios y castas que se agruparon en torno al cura de Dolores, integraban estas primeras partidas de insurgentes ayudantes de las haciendas, desertores del ejército, fugados de presidios y aventureros. A ellos se unieron, aunque en corto número al principio, algunos eclesiásticos, abogados y militares. No consideraba Pérez que se pudiera sospechar siquiera de esos primeros grupos armados que abrigaran los más mínimos deseos de independencia, por cuanto invocaban la autoridad de Fernando VII. La ingenuidad más completa inspiraba algunos párrafos del informe, aunque a la vista de la futura trayectoria política de Pérez cabe pensar en una intencionalidad velada de restar importancia a aquellos sucesos:

"En la América Septentrional nunca ha habido una revolución rigurosa contra el Gebierno Esporiol, porque ésa no se cons-

16 Cfr. nota 2; Lafuente Ferrari, E.: El virrey Iturrigaray..., pág. 332, y Real Díaz J. J. y Heredia Herrera, A. M.: $\varangle$ El Virrey don José de Iturrigaray», págs. 304-327. 
tituye por una facción de bandidos, que hoy aquí, y mañana allá, cometen excesos y atrocidades, sino por una subversión del orden social establecido, en que entren las autoridades y jerarquías de los tres órdenes, militar, civil y eclesiástico, como sucedió en Santa $\mathrm{Fe}$, donde hasta llegó a publicarse la Constitución impresa que todos vimos en Cádiz, con el título de Constitución de Cundinamarca. La Nueva España ha estado siempre, y ahora está en comunión gustosa con la antigua, cuyo gobierno y leyes ni un solo instante ha dejado de reconocer.

Resulta asimismo, que aun entre los autores de aquellos disturbios, el nombre de nuestro Soberano el Señor don Fernando VII, siempre ha sido agradable, amado y respetado; aunque por otro respecto sea muy doloroso, que tuviesen la osadía de tomarlo por pretexto de sus infamias). ${ }^{17}$

Es éste el parecer de una persona adscrita por entonces al «partido español», sin que sus ideas hubieran de ser compartidas, ni mucho menos, por los que permanecían fieles al gobierno peninsular.

¿Qué razones se ventilaban en el bando insurgente? Se registra en él idéntica disparidad de criterios. Ignacio López Rayón había recogido la bandera de fidelidad al rey levantada por Hidalgo, pero ni siquiera él se mantuvo congruente con esos principios. Así, cuando escribía a Morelos con motivo de la impresión del Acta de Independencia, destacaba que desde el principio deseó la erección de un cuerpo soberano depositario fiel de los derechos de Fernando VII: tal había sido el proceder de Hidalgo y de Allende, quienes «jamás quisieron ofender la autoridad de un "rey que ha sido sagrado aun en sus corazones». ${ }^{18} \mathrm{Y}$, sin embargo, el mismo Rayón dejaría escapar otras frases que hacen dudar de la sinceridad de aquellas declaraciones iniciales. Cuando comunicaba a Morelos que había apellidado a su Junta «de Fernan-

17 A.G.I., Estado, 40, ramo 68. Informe de don Antonio Joaquín Pérez al duque de San Carlos. Madrid, 18 de mayo de 1814.

18 A.G.I., México, 1.482, Cuaderno 2, 16. Rayón a Morelos. La fecha de la copia es México, 31 de octubre de 1814. 
do VII», decía primero que no se dirigía la guerra contra el rey; pero añadía más adelante:

“Hablemos claro, aunque la hiciéramos haríamos bien, pues creemos no estar obligados al juramento de obedecerlo, porque el que jura de hacer algo mal hecho, ¿que hará? Dolerse de haberlo jurado y no debe cumplirlo [...] Nuestros planes en efecto, son de independencia; pero creemos que no nos ha de dañar el nombre de Fernando, que en suma viene a ser un ente de razón). ${ }^{19}$

Cuesta, en verdad, admitir que de la misma persona procedan unas y otras aseveraciones.

En una carta que, en noviembre de 1812, José María Liceaga dirigía a Rayón, vuelven a plantearse las motivaciones de la guerra. Carlos IV y Fernando VII eran presentados como los primeros traidores a la patria, que «teniendo hacia nosotros la misma consideración que a una manada de ovejas, nos entregaron a Napoleón, y sancionaron nuestra esclavitud con la abdicación de la Corona». ${ }^{20}$

Empeñada España en su lucha por la supervivencia contra los ejércitos franceses, o reviviría, caso de vencer $-\mathrm{y}$ entonces los americanos insurgentes habrían dejado pasar su oportunidad, para quedar reducidos a un estado peor que el anterior-, o sería derrotada: $y$, en esta eventualidad, no convenía poner restricciones a la libertad plena.

Esa identificación de la libertad de los americanos con la ruina de España aconsejaría influir ocultamente para acelerar la muerte de «esta madrastra cruel». Los medios disponibles para este tratamiento eutanásico eran bien elementales: sostener la guerra y estorbar el envío de auxilios a la península. ${ }^{21}$

19 A.G.I., México, 1.482, Cuaderno 2, 17. Rayón a Morelos, Zitácuaro, 4 de septiembre de 1811 .

20 A.G.I., México, 1.480. Liceaga a Rayón, 16 de noviembre de 1812 . Este documento figura como anexo a la carta núm. 9 del virrey Calleja al ministro de Gracia y Justicia, 22 de junio de 1813.

21 Ibídem. 


\section{Preparativos de la guerra}

Existen profundas discrepancias entre los estudiosos en torno a la cuestión de si obedecía o no la lucha a un plan prefijado, en el que se especificaran objetivos que alcanzar a largo plazo.

El capítulo $3 .^{\circ}$ de la Historia del pueblo mexicano de Pereyra se titula «El levantamiento anárquico», un encabezamiento que ya es, de por sí, una definida toma de postura sobre el particular. Según manifiesta este autor, los planes de insurrección, aunque vagos, eran coincidentes en su fin: se pretendía desposeer del mando político a los españoles y, para conseguirlo, se preveía la convocatoria de una representación nacional, única fuente de poder público capacitada para actuar en nombre del rey desterrado. El procedimiento por el que se llevaría a la práctica este proyecto consistía en una insurrección de criollos y mestizos, que

"harían entonces lo que hicieron los españoles con Iturrigaray, esto es, sorprenderlos, sujetarlos a prisión, y en caso de resistencia, expulsarlos del país y secuestrar sus bienes». ${ }^{22}$

Los planes podían ser vagos e inconcretos, pero lo que cada vez se advierte con más claridad es que obedecían a una preparación remota.

22 Pereyra, C.: Historia del pueblo mexicano. 2 vols. México, s./a., tomo II, pág. 18. Pereyra enfatiza la crisis de autoridad 0 , si se preflere, la incombetencia de los políticos: «el desquiciamiento anárquico no venía, pues, de abajo. Se produjo arriba y sólo muy tarde se propagó a las masas» (Pereyra, C.: Bolivar y Washington. Un paralelo imposible. Madrid, 1917, nota 191, pág. 58): cfr. Acevedo, E. O.: Carlos Pereyra, Historiador de América. Sevilla, 1986, págs. 183-184. Esa explicación choca en apariencia con la propuesta por Anna: athe viceroys were not incompetent, but on the contrary, extraordinarily competent politicians and military leaders». The Last Viceroys of New Spain and Peru: An Appraisal, en \&The American Historical Review», 81, febrero 1976, pág. 40. En realidad, Anna no minimiza la crisis de autoridad, simplemente la traslada a instancias superiores: ethe viceroys themselves unwittingly and without recognizing it, disproved the myths upon which Spanish imperial absolutism was based [...], they proved Spanish imperialism unsuited to America [...] Independence [...] was the rejection of a three-hundredyear-old political tradition and of a previously held identity. Opposition alone could not have produced such a profound political change; established authority must first have proved itself invallid, and the viceroys were the principal agentes of established authority» (ibídem, págs. 39-40). 
Navarrete sostiene, a propósito de un informe del virrey Calleja escrito en 1815 y recogido por Gibaja y Patrón, ${ }^{23}$ que el proyecto de independencia de septiembre de 1810 había sido forjado en Nueva Orleans unos años antes: así constaba en un manuscrito de Garibay —conservado entre los papeles de Iturrigaray-, que contenía un plan insurreccional elaborado en aquella ciudad en 1807. Al parecer, ese año se había formado una junta secreta - la «Asociación Americana-», con el objetivo de emancipar América bajo la protección de los Estados Unidos del Norte: ${ }^{24}$ el primer paso de la empresa vendría dado por la toma de Baton-Rouge, donde se haría tremolar el antiguo estandarte mexicano; y, desde allí, se procedería a la liberación de los territorios vecinos, aligerando así a México «de un yugo que aborrece». ${ }^{25}$

Para Gibaja queda fuera de toda duda que fue la masonería la instigadora del proyecto y del entero proceso de independencia. Consta efectivamente que hubo contactos entre la secta y los caudillos de la rebelión. ${ }^{26}$ Aunque faltan pruebas de que Hidalgo y Allende fueran masones, ${ }^{27}$ hay dos testimonios - concordes en lo esencial- que sostienen el parecer de que ambos caudillos per-

23 Gibaja y Patrón, A.: Revoluciones sociales de México. 5 vols. México. 1926, tomo II, pág. 261. El informe de que se habla debería encontrarse en el legajo 1.708, Papeles de Cuba, del A.G.I.: sin embargo, después de una búsqueda concienzuda no hemos podido localizarlo.

24 Navarrete, F.: La Masoneria en la historia y en las leyes de Méjico. México, 1957, pág. 43.

25 Gibaja y Patrón, A.: Revoluciones sociales en México, tomo II, pág. 261.

26 Costeloe, que se vale de datos recogidos por José María Luis Mora, destaca las facilidades proporcionadas por el movimiento masónico en medios de organización y propaganda política. Su programa, según el mismo autor, abarcaba dos aspectos fundamentales: reforma del clero y sistema de gobierno representativo. (Costeloe, M. P.: La Primera República Federal de México (18241835), México-Madrid-Buenos Aires, 1975, pág. 20). Y, sin embargo, a pesar de lo que se recoge en el texto, algunos autores aventuran la posibilidad de que antes de 1811 la masoneria simpatizara con la causa realista - no se olvide la pertenencia a la secta del virrey Azanza-, y no fuera molestada por la Inquisición, muy' probablemente por el hecho de que algunos masones pertenecían a la oficialidad del ejército. Además, como el Santo Oficio de la Inquisición de México estuvo subordinado a las Cortes entre 1808 y 1813 , es natural que los inquisidores encon $\gamma$ traran dificultades para perseguir a los miembros de la masoneria; Greenleaf, $\mathbf{R}$. E.: The Mexican Inquisition and the Masonic Movement: 1751-1820, en $\$$ New Mexico Historical Review», 44. Albuquerque, abril 1969, págs. 107 y 109.

27 Greenleaf, R. E.: The Mirican Inquisition and the Masonic Movement. págs. 107-108. 
tenecieron a la masonería. Uno de ellos viene procurado por una inscripción lapidaria, grabada en la puerta de una logia:

«El Rito Nacional Mexicano. A los ilustres caudillos de nuestra independencia nacional, D. Miguel Hidalgo y Costilla y D. Ignacio Allende, iniciados masónicamente en esta casa el año de 1806 ». ${ }^{28}$

Carecemos, sin embargo, de datos que permitan sospechar que Morelos fuese masón. Tan sólo consta que mantuvo relaciones con los angloamericanos, pero sin que esos contactos impliquen vinculación explícita con la masonería. ${ }^{29}$

Un informe (cuya autenticidad no se puede comprobar, porque no se cita la fuente) del obispo de Valladolid, don ManueI Abad y Queipo, al rey don Fernando, es recogido por Gibaja con objeto de fundar más firmemente sus opiniones. El tema no podía ser otro que la conspiración de masones, que situaba en 1810, cuando ya se habían establecido unas logias llamadas «De Racionales Caballeros» en Cádiz, Londres, Filadelfia y Caracas. Hacia esas fechas se acusó de sedición a un tal Vicente Acuña, residente en Nueva España, que había sido iniciado en la logia del barrio de San Carlos de Cádiz. Enviado a la península, en Cádiz fue proclamada su inocencia, según sostiene el informe, por influjo «de una facción» que le facilitó la vuelta al virreinato. Desde entonces se convirtió en un decidido militante de la secta, que propagó por varias ciudades contribuyendo al establecimiento de logias en Veracruz, Jalapa y México. ${ }^{30}$

No obstante, por la parcialidad del autor del que hemos tomado estos datos - hay quien afirma que Gibaja ve masones detrás de cada esquina-, y por la difícil comprobación de su veracidad, es preciso acoger con reservas esas informaciones, en espera de poder constatarlas con otros testimonios.

28 Navarrete, F.: La Masonería..., pág. 43.

29 Ibídem, pág. 44. La desvinculación de Morelos con la masonería parece desprenderse también de algunas apreciaciones negativas que se contienen en el discurso que pronunció en el Congreso de Chilpancingo el 14 de septiembre de 1813 (vid. infra).

30 Cfr. Gibaja y Patrón, A.: Revoluciones sociales de México, tomo II, págs. 259-260. 
Como muestra de la curiosa mezcla de las nuevas ideas y del espíritu «tradicionalista», que justificaba el levantamiento como medio de sustraerse a la «perdida» España, hemos recogido el plan de independencia formulado en 1808 por fray Melchor de Talamantes. ${ }^{31}$ Este y otros precedentes permiten sostener que la rebelión de 1810 no se vio tan huérfana de ideas y de orientación práctica como suponía Pereyra.

Era Talamantes un fraile mercedario, de origen peruano, que, ante la gravedad de la situación provocada por criollos y peninsulares, y después de que fuese conocida la abdicación de Fernando VII, llegó a elaborar un plan de actuación que preveía, en primer término, la convocatoria de un Congreso Nacional que

(revistiese al Reino de Nueva España de aquel carácter de dignidad, grandeza y elevación que debía hacerlo respetable entre las naciones cultas e independientes de América y Europa). ${ }^{32}$

La soberanía radicaría en el Congreso, verdadero exponente de la voluntad de la nación. Las atribuciones del órgano soberano quedaban sintetizadas en los siguientes puntos:

- nombrar al virrey capitán general del reino y confirmar en sus empleos a los demás cargos;

- proveer las vacantes civiles y eclesiásticas;

- trasladar a la capital los caudales del erario, y arreglar su administración;

- convocar un concilio provincial para estudiar los medios de suplir en Nueva España lo que estaba reservado a la Santa Sede;

- restringir la Inquisición a su autoridad espiritual, con sujeción al metropolitano;

- requisar la correspondencia de los particulares en que se insinuase algo contrario al gobierno;

31 La figura de este fraile mercedario y sus proyectos independentistas ocupan numerosas páginas del trabajo de Lafuente Ferrari, E.: El virrey Iturrigaray...; véanse, en particular, págs. 91-95, 115-116, 155-156, 177-180 y 275-277.

32 Matute, A.: México en el siglo XIX. Antología de fuentes e interpretaciones históricas. México, 1972, pág. 206. 
- conocer y determinar los recursos reservados por las leyes al rey;

- extinguir mayorazgos, capellanías y pensiones de los residentes en Europa;

- declarar extinguidas las deudas pendientes entre la metrópoli y esa parte de las Américas;

- extinguir la consolidación y arbitrar medios de indemnización a los perjudicados;

- suprimir los subsidios y contribuciones eclesiásticas, salvo las de media annata y dos novenos;

- eliminar las trabas del comercio, minería, agricultura e industria;

- establecer relaciones diplomáticas con los Estados Unidos del Norte.

Realizado este programa, debería tratarse de la sucesión a la corona de España y de las Indias: la persona que fuera designada tendría que ser reconocida por el Congreso como legítimo soberano, y debería jurar acatamiento a las actuaciones del Congreso, y confirmar en sus empleos y destinos a cuantos hubiesen sido nombrados por el Congreso de Nueva España para el ejercicio de aquellos cargos. ${ }^{33}$

\section{Los programas absolutista y liberal}

Viva fue la polémica en España sobre cuál de estas dos formas de gobierno resultaría más apta para impedir la pérdida de los dominios americanos. Los hechos mismos permiten conjeturar la inviabilidad del sistema constitucional, garante de unas libertades que los rebeldes no empleaban sino en contra del sistema. ${ }^{34}$

33 Ibidem, págs. 206-208. Los textos proceden de García, G.: Documentos históricos mexicanos. Obra conmemorativa del primer Centenario de la Independencia de México, 7 vols., México, 1910, tomo VII, págs. 346-358.

34 Ferrer Muñoz, M.: La Constitución de Cádiz y los comienzos de la independencia de México (en prensa), particularmente los capítulos 2 a 4 . «La Constitución tenía una atracción inmediata [en América], pues trataba de conciliar las nuevas ideas liberales con el pensamiento tradicional español; en otras palabras, nato 
La política de atracción se reveló ineficaz, por lo que empezó a practicarse una intensa represión a partir del retorno a España de Fernando VII. El problema consiste en determinar si a largo plazo conducía a buen término el régimen reimplantado por el monarca. En definitiva: si las instituciones eran liberales, insensiblemente contribuían a facilitar la separación entre ambos territorios; si opresivas, podían provocar una explosión más violenta, y causar el mismo efecto. ${ }^{35}$

Infante escribía en 1820 sobre la enorme sima que se abría de modo irreparable entre la península y Nueva España. Sus razonamientos pretendían explicar por qué la Corona acertaba todavía a retener sus posesiones norteamericanas y cómo podía evitarse la ruptura; aunque se hacía eco del sentir general, que daba por perdidos esos territorios en un plazo muy breve de tiempo.

En su opinión, era evidente que si se hubiesen respetado las antiguas instituciones que regían la administración municipal de América, y se hubiese adoptado el criterio de Macanaz, que abogaba por la entrega a los naturales del país de los principales cargos de la administración, América hubiera alcanzado la emancipación mucho antes. ${ }^{36}$ Advertía, por eso, de los peligros de la

a los grupos de la 'élite' criolla, ya muy influidos por las corrientes liberales de España, Inglaterra y Francia, les parecía un modo excelente de conseguir un 'modus vivendi' para sus relaciones con la madre Patria, debido especialmente a que la Constitución abolía el antiguo lazo de unión de las Indias con la Corona - los cuatro Virreinatos- y en su lugar proclamaba la unión de todos los españoles». Stoetzer, O. C.: La Constitución de Cádiz en la América española, en «Revista de Estudios Políticos», 125. Madrid, 1962, pág. 641; desde este punto de vista, por tanto, incluso eran maniflestas las ventajas del nuevo régimen. El problema se planteaba, sin embargo, en la realidad histórica concreta en la que debían plasmarse los principios constitucionales. Las repercusiones en América de la legislación emanada de las Cortes han sido estudiadas por Rodríguez, M.: El experimento de Cádiz en Centroamérica, 1808-1826, México, 1984, págs. 108-138, y Anna, T. E.: The Fall of the Royal Government in Mexico City, págs. 98-139.

35 Sobre las limitaciones institucionales que condicionaban la actuación de los regímenes absolutista y constitucional, cfr. Anna, T. E.: España y la Independencia de América. México, 1986, págs. 14-15 y 147-148.

36 Don Rafael Melchor de Macanaz es una de las principales figuras de la política española en el siglo XVIII, autor también de numerosos trabajos literarios. En una de las obras que se le atribuyen, cuestionaba la soberanía de los reyes españoles sobre América y denunciaba los abusos que se cometían en el Nuevo Mundo; y en una importante Representación a Felipe V sostenía la conveniencia de que se diera más protagonismo a los americanos en la gestión de sus propios 
puesta en vigor de la Constitución, por cuanto suponía una vigorización de las energías locales, que habría de producir irremediablemente la separación. Si el gobierno español dispusiera de una economía saneada y de una marina importante, cabría abrigar alguna esperanza, pero las circunstancias del momento privaban a España de esos medios, por lo que el abandono era inevitable. ${ }^{37}$

La independencia de Nueva España no podía ser contemplada con una actitud comprensiva por la metrópoli, en la que seguía prodigándose el tópico del americano incapaz de gobernarse por sí mismo, opinión de la que participaban, entre otros, Torrente, Beruete y el mismo ministro Lardizábal. Gil Munilla ${ }^{38}$ recoge unas palabras de Benedetto Croce, tomadas de su Historia de Europa en el siglo $X I X$, que resultan muy clarificadoras: «no podía, en suma, el absolutismo volver a la sociedad europea a una estática de tiempos remotos, que además no había existido nunca, y que, por tanto, era una estática imaginaria»: la Reconquista —una vez que España perdió sus colonias - fallaba por las mismas razones que fallaba la Restauración. Por mucho que el Antiguo Régimen se empeñara en impedir la pérdida de sus colonias, su momento histórico había pasado, y carecía ya de resortes que articularan y dieran cohesión a sus esfuerzos.

Además, la ausencia de Fernando VII y los reveses militares de España ante los ejércitos franceses durante el período de actividad de las Cortes coincidieron con los primeros movimientos

asuntos: «parece poco conforme a la razón que carezcan aún de tener en su propia casa manejo» (cfr. Ezquerra, R. de: La crítica española sobre América, páginas 310-312).

37 Cfr. Infante, J.: Solución a la cuestión del derecho sobre la Emancipación de la América. Cádiz (Imprenta de Roquero) y Puebla (Imprenta de don Pedro de la Rosa), 1820, págs. 4, 8 y 11. Los asuntos americanos habían experimentado un giro radical en sólo cincuenta años: así, para un cortesano de Carlos III las tierras de América no eran sino una extraordinaria fuente de riquezas. La conflanza en los recursos de la Monarquía era ilimitada, y su marina recogía los frutos del esfuerzo que se inició en el reinado de Fernando VI (côr. Cepeda Adán, J.: La política americana vista por un cortesano de Carlos III. «Anuario de Estudios Americanos», tomo XXI, Sevilla, 1964, pág. 439). En cambio, el panorama que se vislumbraba en la segunda década del siglo XIX era profundamente pesimista: destrozada la economía del Virreinato de Nueva España, había que intentar, al menos, evitar la derrota militar.

38 Cfr. Gil Munilla, O.: Un proyecto de reconquista de Nueva España. «Anuario de Estudios Americanos», tamo VI, Sevilla, 1949, págs. 555-648. 
emancipadores, que se desarrollaron, pues, en un ambiente de liberalismo político.

A la primera parte de la lucha, que terminó en Bailén y permitió la expulsión de Madrid del rey intruso, siguió la fase de los triunfos franceses, inaugurados personalmente por Napoleón. La ininterrumpida serie de éxitos de los invasores pareció avalar el generalizado convencimiento de que la causa de Fernando VII perdía cualquier esperanza de supervivencia. Por tanto, nada arriesgaban los americanos partidarios de la ruptura con España cuando invocaban el nombre de Fernando, seguros como estaban de que nunca el rey legítimo recuperaría su trono.

"La seguridad de que los españoles, a pesar de su heroísmo, no vencerían la invasión napoleónica, la exasperación que producía la extracción constante de numerario ( 11 millones en 1809 y 1810) para favorecer una causa perdida, el mezquino decreto de la Junta Central concediendo a cada une de los Virreinatos americanos el derecho de hacerse representar en la Central por un diputado, producían una tensión indecible en los ánimos). ${ }^{39}$

Las nuevas disposiciones de las Cortes y el propio articulado de la Constitución contribuyeron a robustecer los sentimientos independentistas, alentados por el mayor protagonismo concedido a los ciudadanos por el régimen constitucional, que ponía en manos de los americanos la posibilidad de designar sus representantes en las Cortes y de decidir la configuración de los nuevos ayuntamientos.

\section{Algunos aspectos sobre la marcha de la guerra basta 1815}

Un estudio detenido de los avatares bélicos nos distraería del objetivo principal de nuestro trabajo. Es, por otra parte, un tema exhaustivamente tratado en cualquiera de las historias de México contemporáneo. No podemos prescindir, sin embargo, de unas

39 Sierra, J.: Evolución política del pueblo mexicano, México, 1940, pág. 163. 
referencias breves: a un esquema general muy sencillo ${ }^{40}$ hemos añadido algunas notas —extraídas de la documentación consultada en el Archivo General de Indias-, que corresponden a los sucesivos balances de la situación elaborados por Calleja $y$ a las infor. maciones sueltas del diario de los Guadalupes, ${ }^{41}$ que muchas veces corroboran y otras desmienten los datos proporcionados por el virrey.

La guerra dura de 1810 a 1821 , y puede dividirse en dos fases claramente delimitadas: 1) 1810-1819 (período al que Bravo Ugarte llama «Guerra Insurgente») y 2) 1820-1821 («Guerra Nacional», también en la terminología de Bravo Ugarte). Sólo, pues, la primera parte - y no en su totalidad - constituye el objeto de nuestro estudio.

La primera fase, a la que se llama también «Guerra Civil», ${ }^{42}$ se distingue por un carácter más bien anárquico y por las dificultades en que se vieron Hidalgo y sus sucesores en el mando para ejercer la dirección de las operaciones. Cabe distinguir dentro de ella varios períodos:

a) De mayor extensión (1810-1811). Hidalgo es el caudillo más importante y principal protagonista de los acontecimientos bélicos. La insurrección se extiende al norte y hacia ambas costas: avanza al noroeste, por Jalisco, Aguascalientes 'y Zacatecas, hasta Nayarit y Sinaloa; y hacia el noreste, por San Luis de Potosí, hasta Coahuila, Nuevo León, Tamaulipas y Texas.

40 Nos hemos servido, en lo fundamental, del trazado por Bravo Ugarte: cfr. Bravo Ugarte, J.: Historia de México, 3 vols., México, 1944-1970, tomo FFI, págs. 49-95.

41 Los Guadalupes constituían una sociedad secreta, al servicio de la independencia, asentada en la misma capital del virreinato. Mantenían informados a los cabecillas rebeldes de cuanto ocurría en México: tanto el diario como las cartas que escribían a los dirigentes de la revuelta abundan en datos precisos y noticias en las que se paladea el sabor del rumor callejero, elaborado a partir de las informaciones obtenidas por agentes infiltrados en instancias oficiales.

42 Lo apropiado de este nombre se confirma por la composición de los ejércitos: las tropas virreinales que combatieron a Hidalgo estaban formadas, en un $95 \%$, por mexicanos. De los 32.000 hombres que componían la fuerza militar de Nueva España antes de la guerra, sólo 10.620 eran veteranos españoles: the backbone of the royalist force remained creole and mestizos» (Anna, T. E.: The Independence of Mexico, pág. 69). 
b) De máxima intensidad (1811-1815). Los principales dirigentes rebeldes son ahora Morelos y Rayón, sin que llegue a alcanzarse la unidad de mando. La guerra se localiza en el centro, aunque también afecta a Guerrero, Oaxaca, Puebla y Veracruz; se produce el relevo de Venegas por Calleja al frente del virreinato, en marzo de 1813, y se celebra - a fines de ese mismo año- al Congreso de Chilpancingo, que concluye con la declaración de independencia.

Centraremos nuestra atención en el segundo período de la primera fase de la guerra, que encaja en el marco cronológico en que se desenvuelve este trabajo.

Derrotado Hidalgo por Calleja en el Puente de Calderón, el 17 de enero de 1811, fue alcanzado en su fuga por Allende y los otros jefes y despojado del mando, que recogió Rayón. Este resucitó el programa de Hidalgo, en posición a Morelos, que no quería seguir hablando de los «derechos del Rey». En agosto de 1811, se juntaron en Zitácuaro Rayón y otros caudillos para elegir los vocales de la Junta Nacional. Resultaron nombrados Rayón, Liceaga y Berduzco, a los que más tarde se agregó Morelos. Simultáneamente, en el orden ideológico, debe destacarse la labor desarrollada por el cura don José María Cos, que comenzó en Sultepec la publicación de un semanario con el título de El Ilustrador Nacional, al que siguió luego El Ilustrador Americano.

Si hay algo que distingue a esta primera etapa de la guerra es la adopción de las más rigurosas medidas por uno y otro bando: esta lucha de exterminio condujo a un progresivo endurecimiento de las posiciones, reforzado por el acceso de Calleja al virreinato. ${ }^{43}$

43 Un botón de muestra lo proporciona el decrelo que Calleja publicó el 5 de enero de 1812, después de la toma de Zitácuaro. Entre otras disposiciones, preveía la confiscación de las tierras y bienes de los rebeldes y la completa destrucción de la villa de San Juan de Zitácuara con la expresa prohibición de «volver a fundar en adelante pueblo alguno en eske Jugar» (cfr. Bustamante, r. M. de: Cuadro Histórico de la Revolución Mexicana iriciada el 15 de septiembre de 1810 por el C. Miguel Hidalgo y Costilla cura del pueblo de Dolores en el obispado de Michoacán, 3 vols., México, 1961, tomo I, págs. 242-244). Lynch atribuye a las fuerzas realistas la iniciativa en estas prácticas represivas: ante la provocación de lo que el mencionado autor califlca de «terrorismo realista», «Morelos adoptó el incendiarismo y la guerra a muerte. Después de la derrola de Valladolid, y como reacción por la práctica realista de fusilar a los prisioneros, promulgó órdenes de 
A finales de mayo de 1813, cuando sólo habían transcurrido dos meses desde que se confiara el mando en Nueva España a Calleja, hizo éste una recapitulación sobre la marcha de la guerra, que parecía orientarse por nuevos derroteros. Desde hacía dos años y medio, los Villagrán - padre e hijo- ocupaban Zimapán y Huichapan; quince meses llevaba Rayón fortificado en Tlalpujagua, cerca de los caminos que comunicaban México con Querétaro y Valladolid; otros tantos meses duraba la permanencia en Zacatlán de Osorno, con un ejército de seis mil hombres que interrumpía el camino de Puebla.

$\mathrm{Y}$, sin embargo, todos esos centros de resistencia habían sido desalojados en poco menos de dos meses. Los hermanos Rayón fueron derrotados en Salvatierra, y Liceaga en Puruándiro, provincia de Michoacán, el 24 de abril. Morelos trató de pasar a Puebla, desde Oaxaca, pero hubo de retroceder ante las fuerzas que mandaba el conde de Castro-Terreño. Perseguido por una división de las tropas de Guatemala, dirigió su ejército a Acapulco, de cuyas inmediaciones hizo retroceder a una división mal organizada, que debía asegurar la provisión de víveres al castillo que dominaba el puerto que, por este motivo, estuvo a punto de caer en manols de Morelos.

En el interior del reino, derrotados los rebeldes de El Bajío y Guanajuato, habían quedado reducidos a pequeñas guerrillas. El estado de Nueva Galicia era semejante, a pesar de las quejas de su comandante general, don José de la Cruz, que se lamentaba de la falta de auxilios. La realidad, en opinión de Calleja, èra más optimista: ni escaseaban los recursos económicos, ni faltaban tropas.

Más hostigada estaba la provincia de Michoacán, uno de los principales focos de actividad insurgente. San Luis Potosí, Zacatecas, Durango y Sonora se encontraban, en cambio, en absoluta tranquilidad, aunque expuestas a las consecuencias de la ocu-

matar a todos los prisioneros militares y devastar los pueblos y haciendas colaboracionistas» (cfr. Lynch, J.: Las revoluciones hispanomericanas 1808-1826, Barcelona, 1976, pág. 353). 
pación de Texas por Bernardo Gutiérrez que, en abril, se había apoderado de la villa de San Fernando, su capital. ${ }^{44}$

La unificación militar que habían pretendido alcanzar los rebeldes con la reunión de Zitácuaro en agosto de 1811 resultó un fracaso. De aquella experiencia extrajo Morelos la idea de un gobierno democrático, con un Congreso y un Ejecutivo, que tampoco habría de resultar: el 14 de septiembre de 1813 se reunía el Congreso de Chilpancingo, en el que se eligió un generalísimo y cesó la autoridad de la Junta, que fue disuelta por Morelos el día 18 del mismo mes.

La declaración de independencia se produjo el 6 de noviembre, y con ella culminaban las aspiraciones del Congreso. Sin embargo, los fracasos militares de Morelos ${ }^{45}$ aconsejaron al Congreso privarle del poder ejecutivo, que pasó a ser compartido por Liceaga, el propio Morelos y Cos. Tampoco funcionó la fórmula tripartita, que alimentó continuas disensiones que forzaron la retirada de Cos: éste llegó a acusar al Congreso de ilegítimo — sus componentes se habían elegido a sí mismos- y de traición, por haberse vendido a las autoridades españolas. Aprehendido por Morelos, fue condenado a prisión perpetua.

A finales de 1813 , el balance parecía bastante positivo para las tropas españolas, aunque persistía una tenaz resistencia por parte de los sectores independentistas ${ }^{46}$ y las armas realistas no acababan de afianzar su dominio en los territorios ocupados: la falta de medios y la explotación incompleta de las victorias explican, parcialmente, que los éxitos militares no fueran decisivos y que para el año 1814 se avizorara un panorama nada halagüeño.

Las medidas de gracia que otorgó Calleja tuvieron escasa repercusión y, desde luego, no se revelaron nada beneficiosas para

44 A.G.I., México, 1.480. Calleja al ministro de Gracia y Justicia, núm. 5, México, 31 mayo 1813.

45 Con posterioridad al Congreso, Morelos emprendió una ambiciosa campaña con objelo de apoderarse de Michoacán. Su fracaso en Valladolid significó el comienzo de una serie de tropiezos que permitirían la recuperación por los ejércitos virreinales de Acapulco y de Oaxaca. pág. 123.

46 Cfr. Torrente, M.: Historia de la independencia de México. Madrid, 1918, 
la causa de los españoles: muchos de los que se acogieron a esos indultos seguían siendo insurgentes encubiertos, que se mantenían a la expectativa de cualquier ocasión propicia para su causa. Esta fue la razón por la que se publicó un bando el 22 de junio, que limitaba a treinta días el plazo para quienes quisieran beneficiarse del indulto: expirado ese tiempo, no habría ya posibilidad ninguna de obtener la gracia. ${ }^{47}$

Una carta de Calleja al ministro de Ultramar, fechada en octubre de 1814, evaluaba los efectos que en el bando rebelde había causado el decreto del 4 de mayo: en aquellas fechas no quedaba ya ninguna provincia controlada por los insurgentes -como ocurriera antes en Oaxaca y en su capital, desde donde extendían su influencia a toda la provincia de Puebla-, aunque retenían la fortaleza y puerto de Acapulco y mantenían su predominio en casi toda la costa del sur, tenían, en fin, un gobierno y una autoridad común que era reconocida por casi todos los cabecillas.

Mucho habían cambiado las cosas en octubre: dispersas las fuerzas rebeldes, éstos se veían obligados a vagar de lugar en lugar; y aunque seguían asolando el país, su ejército había perdido casi toda su eficacia.

A raíz del regreso de Fernando VII a España, Calleja estimó oportuno informar del hecho y divulgar cuáles eran la voluntad y los designios del rey: «el resultado es que los rebeldes se han quitado la máscara y negado la obediencia al Rey Nuestro Señor, y aunque fue siempre una mera hipocresía...», se habían descubierto sus verdaderas intenciones. ${ }^{48}$

Al mismo tiempo que el virrey remitía sus extensos informes a las autoridades peninsulares, los Guadalupes ponían en conoci-

47 A.G.I., México, 1.485. Calleja al ministro de Gracia y Justicia, núm. 108, México, 13 de julio de 1814 .

48 A.G.I.. México; 1.483. Calleja al ministro de Ultramar, núm. 16, México, 31 de octubre de 1814. La política emprendida con posterioridad a los sucesos peninsulares de mayo de 1814 significó un cambio radical en el modo de plantear el problema de la insurrección americana: si hasta entonces las poscuras de fuerza se compaginaban con concesiones y reformas, la nueva situación se caracterizó por una escalada militar, que permitió la rápida reunión de dos mil soldados que debían ser enviados a Nueva España, para incrementar las fuerzas con las que el virrey se proponía asegurar la paz. Costeloe, M. P.: Response to Revolution. Imperial Spain and the Spanish American Revolution, 1810-1840, Cambridge, 1986, págs. 60-61. 
miento de los cabecillas rebeldes cuanto ocur:bry en la capital de Nueva España y les comunicaban su entusiasmo por los éxitos de las armas insurgentes: así, el 18 de noviembre de 1813, contaban la difusión que alcanzaron en México las noticias de la caída de Celaya en manos rebeldes y de la llegada de seis mil angloamericanos a Cuernavaca. Según otro de sus escritos, el 30 de diciembre se daba por sentado en México que los españoles habían sido desalojados de Valladolid, aunque se desconocieran pormenores de la operación. ${ }^{49}$

Después de que Morelos fuera capturado por las tropas virreinales (noviembre de 1815) prosiguieron las disidencias. Se acordó entonces la disolución de los Tres Poderes, y una Comisión Ejecutiva reemplazó al anterior gobierno. Comenzaba así el período de decadencia.

\section{Puntos conflictivos}

Desde le provincia de Michoacán, que fue el principal centro de operaciones de los rebeldes durante mucho tiempo, las acciones insurgentes mantuvieron en jaque a todo el territorio del virreinato. Por eso, en rigor no debe hablarse tanto de puntos conflictivos como de las dificultades que aquejaban a todas y cada una de las provincias. Naturalmente, ese intento dificultaría notablemente la comprensión de la marcha de la guerra y degeneraría, con suma facilidad, en una intrincada relación de golpes de mano. Limitaremos, pues, nuestra observación a los lugares en que la conflictividad fue mayor.

\section{La adquisición de la Luisiana por Estados Unidos}

Jefferson, presidente de los Estados Unidos de Norteamérica, adquirió por compra -en 1803 - el territorio de la Luisiana, que fue vendida por Napoleón, entonces primer cónsul. Con

49 A.G.I., México, 1.482. Diario de los Guadalupes. Cuaderno 4. 
diferencia de días, Monroe, enviado por Jefferson, inició las gestiones para la compra a España de Florida occidental, incluido el puerto de Mobila, cuya posesión se juzgaba indispensable a partir del momento en que Nueva Orleans se convirtiera en una gran potencia marítima. Desde los primeros contactos, el gobierno norteamericano pretendió que Florida occidental había sido comprada con la Luisiana, por estar comprendida en sus límites. A la oposición enérgica de España replicaron los angloamericanos con nuevas insistencias, que desembocaron en la decisión unilateral por la que Madison, en 1810, declaraba anexionado el territorio en disputa. ${ }^{50}$ Agregábase a la gravedad de esta provocación su coincidencia en el tiempo con otro acontecimiento fundamental: la invasión de España por Napoleón.

Desde estos momentos la Florida constituyó un punto de litigio permanente. Interesada la Regencia española en atraerse a sus habitantes, en diciembre de 1812 concedió un indulto al que podían acogerse quienes hubiesen tomado parte en la invasión de Florida oriental y occidental. ${ }^{51}$ En efecto, también estos territorios pretendían separarse de España, y en sus costas se habían establecido varias guarniciones insurgentes en las que la disciplina brillaba por su ausencia. Luis de Terán, a propósito de una de ellas, comentaba que el orden no era mayor allí que el que se observa a bordo de un barco corsario. Además era grande el interés que tenían los Estados Unidos en adueñarse de la isla de Amelia, próxima a estas costas, donde radicaba el más importante centro de trata de negros. Sus conversaciones con el gobierno de Madrid dieron fruto 'y obtuvieron la cesión de la isla. ${ }^{52}$

No fue éste el único problema que la venta realizada por el primer cónsul planteó en las relaciones fronterizas entre Nueva España y Estados Unidos. La marcha al oeste de los angloamerica-

50 Pereyra, C.: Texas. La primera desmembración de Méjico, Madrid, s./a., págs. 19-21.

51 A.G.I., México, 1.480. Calleja al ministro de Gracia y Justicia, núm. 28, México, 30 de abril de 1813 .

5¿ Terán. L. de: Memorias de un oficial de la Legión Británica. Camparias y cruceros durante la guerra de emancipación Hispano-americana, Madrid, s./a., págs. 9-21. 
nos, que coincidía con la grave crisis de 1808 , preocupaba a las autoridades españolas. Este temor se refleja en el informe que don Nemesio Salcedo, entonces comandante general de las Provincias Internas, escribía a la Junta de Sevilla:

“El genio inquieto y codicioso de nuestros vecinos los anglo-americanos, el carácter vacilante y anárquico de su Gobierno, los hombres revoltosos que encierra en su seno y la debilidad de su Constitución y leyes, para poder descansar sobre su fe y palabra, me hace recelar de su parte alguna agresión, en unas circunstancias que, quizá, estimarán las más oportunas». ${ }^{53}$

Salcedo elaboró un proyecto, al que llamó «Plan de oposición a las empresas de la República de los Estados Unidos de América», en el que explicaba las bases en que debía apoyarse la defensa del territorio español. Los pasajes más relevantes de su informe atañían a la crítica situación de la provincia de Texas: sus puertos se hallaban insuficientemente defendidos, y su lejanía con respecto a San Luis de Potosí - principal base militar de los alrededorescomplicaba sobremanera el transporte de tropas.

Esos temores ante la eventualidad de una acción armada de los vecinos del norte se veían acrecentados por las previsibles dificultades en la absorción de los habitantes de la Luisiana que pratendían establecerse en Nueva España. ${ }^{54}$

Coincidían estos sucesos con un sensible descenso en la producción de las minas de las Provincias Internas, cuya economía giraba en torno a las actividades extractivas: sobre todo desde que, en 1803, se descubrieron nuevos e importantes yacimientos de cobre en la Sierra de este nombre, donde se inició también la explotación de un placer y una veta de oro. Desde 1808, las minas y placeres de Cieneguilla, Mulatos, Cobre y Mapimí y Hornillas empezaron a rendir de manera más irregular. La difícil coyuntura

53 Artola, M.: La guerra de Independencia y las Provincias Internas. «Revista de Indias», núm. 46, Madrid, 1951, págs. 763-772.

54 A.G.I., México, 1.638. Calleja al ministro de Hacienda, núm. 128, México, 30 de septiembre de 1813 . 
se agravó cuando la Real Hacienda suspendió la compra de cobre, porque disponía ya de cantidad suficiente y porque el erario se veía apremiado por más urgentes necesidades. Otros factores que incidieron en el descenso de la producción -que alcanzó su nivel ínfimo en 1812 - eran la interrupción de comunicaciones con México que proveía a la región de azogue, herramientas y ropas, y la dispersión de la población a causa de las primeras actividades insurgentes. ${ }^{55}$

Texas ${ }^{56}$

De una manera o de otra, lo cierto es que la suerte de las provincias limítrofes con la Luisiana era, por lo menos, incierta. Así se explican los urgentes requerimientos al gobierno central en relación con las negociaciones fronterizas. ${ }^{57}$

El peligro revestía especial gravedad en Texas, adonde se había mandado una expedición - los tercios de Texas- desde la península, que no llegó a desembarcar al haber sido apresadas por los ingleses las fragatas que debían transportar a las tropas. ${ }^{58}$ En noviembre de 1813 la situación era insostenible: el día 3 de ese mes se enfrentaron las tropas españolas que mandaba Arredondo con grupos armados angloamericanos que, según los Guadalupes, eran «gente venida a auxiliar a nuestra insurrección por orden y!

55 Navarro García, L.: Las Provincias Internas en el siglo XIX, Anuario de Estudios Americanos», tomo XXI, Sevilla, 1964, págs. 247-379.

56 En Florescano, E. y Gil, I. (comps.): Descripciones económicas regionales de Nueva España. Provincias del Norte, 179a1814, México, 1976, págs. 152-200, se recoge la memoria que, en la sesión de Cortes de 7 de noviembre de 1811, presentó Miguel Ramos Arizpe, diputado por Coahuila, sobre la situación de las Provincias Internas de Oriente (Nuevo Reino de León, colonia del Nuevo Sartander, provincia de Coahuila y provincia de Texas). La información que ahí se recoge facilita un conocimiento bastante detallado de las peculiaridades geográficas, económicas, administrativas y militares de ese territorio. Sobre las acciones promovidas por los Estados Unidos en Texas, véase Gronet, R. W.: The United States and the Invasion of Texas, 1810-1814. «The Americas», 25, Washington, D. C. 1969, págs. 281-306.

57 A.G.I., Estado, 31, ramo 24. Calleja encargó a fray José Pichardo las correspondientes gestiones con los representantes de los Estados Unidos: cfr. carta de Calleja al ministro de Estado, México, 15 de marzo de 1813.

58 Ibídem.

Tomo XLVIII

27.-Anuarıo 
acuerdo del gobierno de Estados Unidos». ${ }^{59} \mathrm{La}$ presencia de Arredondo al frente de las fuerzas realistas resultó eficaz; así se desprende de un informe de Calleja, fechado en enero de 1814, en el que relata la notoria mejoría experimentada en la marcha de la guerra en ese territorio. ${ }^{60}$

Por entonces actuaban en Texas los rebeldes José Alvarez de Toledo y Bernardo Gutiérrez, que se había apoderado —en abril de 1813- de la capital de la provincia. A la vista de estos acontecimientos se encargó a Arredondo que acudiera a la frontera para contener al enemigo. ${ }^{61}$

El horizonte del verano de 1813 no aparecía precisamente despejado: hacia julio fue batido el cuerpo de caballería de Coahuila que mandaba el teniente coronel don Ignacio Elizondo; y, además, estaba sublevada parte de Nuevo Santander y de Nuevo León, y habían caído en poder de los rebeldes algunas ciudades de la primera de esas provincias.

No obstante, a principios del nuevo año parecía observarse una reacción de las armas españolas. Arredondo había disuelto a los grupos insurgentes, y los restos de esas partidas fueron perseguidos por Elizondo hasta más allá de la frontera con Luisiana; recuperada la capital, Béjar, Arredondo concentró allí todas las tropas del oeste y sur de la provincia; el coronel don Cayetano Quintero al frente de una división de caballería, había tomado Nacogdoches y castigado a los indios que prestaron ayuda a los rebeldes. La perspectiva era incomparablemente más lisonjera y, como muestra de buena voluntad, se concedió el indulto a los habitantes de Texas que lo solicitaron y a las tribus de indios que vivían en la provincia.

Arredondo se mantenía informado de los nuevos proyectos que abrigaban Gutiérrez y Alvarez de Toledo, y recelaba de los

59 A.G.I., México, 1.482. Diario de los Guadalupes, Cuaderno 4. Morelos transmitió instrucciones a algunos emisarios insurgentes para que negociaran el territorio de Texas a cambio de la ayuda norteamericana. Elguero, J.: España en los destinos de México. Madrid, 1942, págs. 100-101

60 A.G.I., México, 1.484, Calleja al ministro de Estado, núm. 9, México, 24 de enero de 1814.

61 A.G.I., México, 1.480. Calleja al ministro de Gracia y Justicia, núm. 5, México, 31 de mayo de 1813. 
angloamericanos, que habían ocupado la zona neutral. Por todo esto consideraba conveniente la formación de varios cuerpos de ejército en los territorios que se hallaban bajo su mando: un criterio que no era compartido por Calleja, por la disminución de brazos en la agricultura y la ganadería que implicaban las nuevas reclutas. ${ }^{62}$

El virrey prefería atenerse a un antiguo plan sobre población civil y militar de Texas, que preveía el envío directo a esta provincia de una expedición de 1.500 a 2.000 hombres que deberían desembarcar en el puerto de Matagorda, ${ }^{63}$ sito en la bahía del Espíritu Santo: se evitarían así el descontento de las tropas que, procedentes de la península, eran trasladadas de las provincias del sur a las del norte, las más afectadas por la insurrección. Tan grande era la resistencia que ofrecían los soldados para servir en este destino que, en la marcha de Monterrey a San Antonio de Béjar, llegó a desertar en su integridad la compañía de Cazadores del regimiento de Extremadura.

En el manifiesto con el que Calleja saludaba el regreso de Fernando VII a suelo español, se contenía una breve síntesis de los últimos sucesos bélicos, entre los que destacaban los ocurridos en Texas. Recordaba el virrey cómo, al principio de la guerra, esa provincia había sido invadida por los angloamericanos, aliados con los rebeldes y los indios de la frontera. La gravedad de la situación obligó a Calleja a enviar a Texas la mitad de las tropas de los regimientos de Extremadura y de Saboya que recién llegados a Jalapa desde la península, debían asegurar las comunicaciones de esa ciudad con Veracruz y Puebla. Además, la eventualidad de una acción insurgente sobre el Nuevo Reino de León obligó a utilizar también la división de Nuevo Santander y de Huasteca.

En el curso de unos cuantos meses, la situación había cam-

62 A.G.I., México, 1.484. Calleja al ministro de Estado, núm. 9, México, 24 de enero de 1814.

63 Reunía este puerto excelentes condiciones para la penetración hacia el interior, y su utilización permitía suplir los inconvenientes de las excesivas distancias por tierra entre las poblaciones de esta zona, facilitándose así el traslado de los nuevos colonos que se pretendía introducir en Texas. A.G.I., México, 1.483. El comandante general de Provincias Internas de Occidente al secretario de Estado y del Despacho de gobernación de Ultramar. Durango, 27 de septiembre de 1814. 
biado de modo sustancial no sólo en Texas sino en el resto del virreinato: asegurado el control de aquella provincia, exterminados los dos grandes ejércitos rebeldes de Morelos y de Matamoros, también Acapulco había sido reconquistado por las tropas reales. Los rebeldes no conservaban otra base militar que la de la laguna de Chapala, «que no tardará en ser su sepulcro» .

\section{La causa insurgente en Michoacán y Guadalajara}

En una carta del obispo Abad y Queipo a Calleja, del 16 de septiembre de 1814 , se incluía un cálculo del total de tropas que los rebeldes habían movilizado en la provincia de Michoacán, que absorbía una parte importante de los ejércitos insurgentes.

Según los datos de Abad y Queipo, los rebeldes contaban con doce mil doscientos hombres, distribuidos entre las diversas partidas que actuaban en ese territorio: con Morelos había dos mil, mil con Manuel Muñiz, otros tantos seguían a Cos, y mil doscientos a Vargas; Navarrete, Sain, Villalonguín y Huerta, que habían juntado sus tropas, reunían entre todos a mil quinientos hombres; Torres mandaba la partida más numerosa, compuesta de cuatro mil soldados; finalmente, había mil con Pachón y quinientos con los hermanos Rayón.

La vecina provincia de Guadalajara se veía amenazada desde marzo de 1814 por las incursiones de Vargas, Cos, Navarrete y Torres. La defendían sólo tres mil hombres, y se había pensado en la posibilidad de abandonarla si no llegaba el esperado refuerzo de dos mil soldados. ${ }^{64}$

Sin embargo, mal concertados entre sí los jefes rebeldes, pronto quedó conjurado el peligro y Guadalajara fue sustraída a la acción insurgente. Ya en el otoño de 1814 había desaparecido cualquier posibilidad de avenencia y coordinación entre aquellos dirigentes independentistas, «esparcidos en el día y vagando de lugar en lugar»: una situación ésta que se hallaba en vivo contraste con la eficacia de las armas insurgentes a lo largo de 1813, cuando

64 A.G.I., Estado, 41, ramo 46. Abad y Queipo a Calleja. Valladolid, 16 de septiembre de 1814. 
poseían Oaxaca y ocupaban gran parte de Puebla y el importante puerto de Acapulco. ${ }^{65}$

LA GUERRA, VISTA DESDE EL BANDO INSURGENTE

Morelos, generalísimo de la insurrección

A los ojos de todos, Morelos pasaba por ser el caudillo indiscutible de los rebeldes de Nueva España. Su personalidad y condiciones excepcionales eran, desde luego, reconocidas por todos, incluidos los realistas, que no ignoraban el influjo que Morelos ejercía sobre las masas de insurgentes.

El diario de los Guadalupes refiere un hecho ocurrido el 24 de noviembre de 1813. La llegada de un correo extraordinario, que portaba malas noticias provocó la indignación del virrey:

"Se enfureció exclamando que todos los proyectos se los frustraba el señor Morelos: uno de los concurrentes que había quedado tan suspenso como los demás, viendo la furia de Calleja, le dijo que si unos proyectos se frustraban, otros se conseguirian, que él era bastante fecundo: a lo que contestó el virrey más alterado, que ya estaba estéril, y tomando la esquelita se metió para otra pieza, sin hablar más palabra). ${ }^{66}$

Aparte del alterado estado de ánimo de Calleja, muestran estas observaciones el elevado concepto que de Morelos tenía el virrey, hasta el punto de atribuirle el fracaso de todos sus proyectos.

El papel rector que desempeñaba este caudillo recibió su confirmación legal cuando el Congreso Nacional convocado por él en Chilpancingo lo nombró generalísimo de las armas mexicanas. Los Guadalupes, que acataban su autoridad antes incluso de que hubiera recibido el nombramiento, expresaban su contento al recibir la noticia:

65 A.G.I., México, 1.483. Calleja al ministro de gobernación de Ultramar, núm. 16, México, 31 de octubre de 1814.

66 A.G.I., México, 1.482. Diario de los Guadalupes. Cuaderno 4. 
"ahora sí que veremos arregladas todas las Divisiones sueltas que con tanto heroísmo han tomado las armas para defender su Patria, y la falta de dirección les hacía separarse de su fin). ${ }^{67}$

\section{Desavenencias entre los jefes rebeldes}

La forzada incomunicación creaba condiciones óptimas para la adquisición por cada caudillo de un poder autónomo, desvinculado de toda autoridad superior. A eso se referían los Guadalupes en el texto arriba citado: hasta la erección de Morelos como generalísimo no había un auténtico poder dirigente de primera magnitud, pues la Junta Nacional antes existente se reveló de ninguna utilidad.

A las distancias y obstáculos geográficos venía a añadirse el problema de las desavenencias entre los vocales. Morelos, conocedor de estas rivalidades, manifestó a Rayón sus proyectos para restablecer la concordia, en una carta que le dirigió en marzo de 1813. Para apaciguar ánimos y prevenir enfrentamientos futuros, Morelos sugería

"que los vocales se releven o remuevan de la Junta con las mismas formalidades que entraron a ella, probado el motivo de su remoción así para satisfacción del Pueblo como para elección de otros individuos, o suplentes y honor de los que entran y salen; pues de lo contrario nadie, ningún hombre de honor querrá entrar en constitución, sabiendo que ha de ser llamado con deshonor el día que como hombre cometa algún yerro, del que no estuvo exento ni el primer hombre, ni el más sabio de los hombres). ${ }^{68}$

Si el plan era aceptado, deberían reunirse los vocales, junto con la oficialidad de cada plana, previa la adopción de las convenientes medidas de seguridad. Se había de procurar que el lugar

67 Ibídem. Los Guadalupes a Morelos. México, 3 de noviembre de 1813. Cuaderno 4.

68 Se trata de una carta de Morelos a Rayón, escrita el 18 de marzo de 1813 y reproducida en Hernández y Dávalos, J. .E: Colección de Documentos para la Historia de la guerra de Independencia de México de 1808 a 1821, 6 vols., México, 1877-1882, tomo IV, pág. 925. 
del encuentro fuera equidistante y, al elegirlo, era preciso tener en cuenta que asistiría también el vocal de Oaxaca, pues sin él no podía procederse a ninguna votación. Como fecha de la reunión se proponía el 8 de septiembre, y el lugar más indicado parecía el pueblo de Chilpancingo, que reunía aquellas condiciones requeridas.

Las diferencias entre Morelos y Rayón estribaban fundamentalmente en sus opiniones encontradas acerca de la publicación del Acta de independencia. El parecer de Rayón había sido expresado en los siguientes trminos:

"Yo cada día encuentro más embarazos para publicarla, porque la que se ha extendido está tan diminuta que advierto expresados en ella unos artículos que omitidos se entienden más, y otros que el tocarlos es un verdadero germen de controversias [...] "¿Qué avanzamos con publicar esa constitución que realmente nada alivia para la administración de justicia y régimen interior? $[\ldots]$.

"Creo, repito, nada avanzamos sino que se rían de nosotros y confirmen el concepto que nos han querido dar los gachupines de unos meros autómatas).. ${ }^{69}$

No era grata a Rayón la promulgación del Acta de independencia porque entendía que el Congreso se justificaba en cuanto fiel depositario de los derechos soberanos de Fernando VII. La abierta declaración de independencia podía ocasionar daños irreparables: la enorme masa de los indios, hasta entonces solidarios de los demás americanos en la común opinión de que tań sólo se trataba de reformar un poder arbitrario, sin sustraerse a la obediencia del rey, se movilizaría una vez declarada la separación. Además, le preocupaba la actitud que pudieran adoptar las potencias extranjeras:

"¿Quién garantiza la neutralidad de las potencias extrañas, principalmente de la Inglaterra, acreedora de la moribunda España

69 A.G.I., México, 1.482. Rayón a Morelos. Puruarán, 2 de marzo de 1813. Cuaderno 2,4 y 5 . 
de una inmensa suma de millones de que sólo puede reintegrarse con la posesión del codiciado reino de México?». ${ }^{70}$

La sombra de estas dudas impedía a Rayón adherirse a las opiniones de Morelos, deseoso a toda costa de proclamar la independencia.

La diversificación de las operaciones militares, principal causa de lo limitado de sus éxitos, era otra de las razones que urgían a Morelos la convocatoria del Congreso del que había de resultar la independencia. Morelos atribuía aquella ineficacia a la confluencia de todos los poderes en los pocos componentes de la Junta, que se veía agobiada por la magnitud de sus tareas. Al mismo tiempo, juzgaba de la mayor importancia que el poder ejecutivo se concentrara en una persona, en cuya designación deberían intervenir los jefes militares a partir del rango de coroneles. ${ }^{71}$

\section{El Congreso de Chilpancingo ${ }^{72}$}

Los éxitos rebeldes culminaron en la celebración del Congreso de Chilpancingo. $\mathrm{Y}$, sin embargo, en los meses que le siguieron empezaría el declive de las armas insurgentes, debido a una compleja serie de razones que no resulta fácil de comprender.

Además de la ya aludida necesidad de coordinar la acción de los dirigentes rebeldes, hubo otras consideraciones que animaron a Morelos a la convocatoria de esta reunión: cabe pensar tanto en la necesidad de endurecer las acciones bélicas (con su inevitable acompañamiento de represalias y crueldades), como en el afán por alzar el sentir antiespañol de la nación y los deseos de independencia que brotaban de ese odio a la metrópoli.

Por otro lado las noticias que llegaban de Europa no resul-

70 Ibídem. Rayón a Morelos (la fecha de la copia es México, 31 de octubre de 1814). Cuaderno 2, 16.

71 Ibídem. Convocatoria del Congreso de Chilpancingo. Cuaderno 2, 6.

72 Una exposición muy clara de los aspectos más destacados del Congreso, en Meyer, M. C. y Sherman, W. L.: The Course of Mexican History, New York, 1979, pág. 292. 
taban tranquilizadoras para el cura mexicano: al mediar 1813, la península se veía casi enteramente libre de la ocupación francesa, y era considerado inminente el regreso de Fernando VII, que privaría de justificación a la causa de la independencia, que siempre había proclamado su fidelidad al rey desterrado. ${ }^{73}$

Aceptado el principio de la división de poderes, una de las primeras decisiones que debía adoptar el Congreso se refería a la designación de la persona que, con el cargo de generalísimo, asur miría la dirección de la guerra. Morelos recibió un respaldo amplísimo, ${ }^{74}$ pero declinó inicialmente la aceptación del poder ejecutivo. Al cabo,

"vencido por las expresiones públicas y por la autoridad del congreso, admitió por fin el empleo con las cuatro condiciones siguientes: 1.-Que cuando vengan tropas auxiliares de otra potencia no se han de acercar al lugar de la residencia de la Suprema Junta.

2.-Que por muerte del Generalísimo ha de recaer el mando accidental de las armas en el jefe militar que por graduación le corresponda haciéndose después la elección como la presente.

3.-Que no se le han de negar los auxilios de dinero y gente, sin que haya clases privilegiadas para el servicio.

4.-Que por muerte del Generalísimo se ha de mantener la unidad del Ejército y de los habitantes). ${ }^{75}$

Los requisitos exigidos por Morelos no eran en realidad más que simples medidas de prudencia tendentes a impedir la desintegración de la unidad de esfuerzos alcanzada después de haber sido sorteados muchos escollos.

En un discurso pronunciado por Morelos el 14 de septiembre, que había sido escrito por don Carlos María Bustamante, se habla-

73 Sierra, J.: Evolución política.... págs. 172-173.

74 A.G.I., México, 1.482. En el cuaderno 1 de la carta número 15 de Calleja al ministro de Gobernación de Ultramar, escrita en México el 31 de octubre de 1814. se contiene una extensa relación con los nombres de todos los que votaron a Morelos como Generalísimo.

75 Ibídem. Entrega del poder ejecutivo a Morelos. Chilpancingo, 16 de septiembre de 1813. Cuaderno 2,11 . 
ba de importantes verdades que no se ignoraban antes pero que el despotismo del gobierno procuró ocultar. Tales eran

"que la soberanía reside esencialmente en los Pueblos [...]; que si transmitida a los Monarcas, por ausencia, muerte o cautividad de éstos, refluye hacia aquéllos que la otorgaron $[\ldots]$; que son libres para reformar sus instituciones políticas siempre que les convenga $[\ldots]$; que ningún Pueblo tiene derecho para sojuzgar a otro, si no precede una agresión injusta». ${ }^{76}$

A partir de estos principios se concluía la legitimidad de la lucha sostenida por los españoles contra Napoleón y, por los mismos motivos, de las pretensiones de independencia de los americanos:

“ ¿Podrán nuestros enemigos ponerse en contradicción consigo mismos, y calificar de injustos los mismos principios con que canonizan de santa, justa y necesaria su actual revolución contra el Emperador de los Franceses?»." ${ }^{77}$

El discurso terminaba con una mirada retrospectiva hacia el pasado, que permitía presentar a los miembros del Congreso como vengadores de todos los ultrajes inferidos por tres siglos de dominación española:

"Genios de Moctezuma, Cacama, Quatimozín, Xicotencal y Calzontzin, celebrad en torno a esta augusta asamblea [...] el fausto momento en que vuestros ilustres hijos se han congregado para vengar vuestros ultrajes y desafueros y librarse de las garras de la tiranía y franc-masonismo, que los iba a sorber para siempres. ${ }^{78}$

La verdad sea dicha, tal invocación, algo trasnochada, no pasaba de ser un recurso poético para embellecer la justicia da una causa cuyos principales beneficiarios eran los criollos, y: no los indios.

78 Ibídem.

76 Ibídem. Discurso de Morelos en Chilpancingo, 14 de septiembre de 1813 , compuesto por don Carlos María Bustamante. Cuaderno 2, 8.

77 Ibídem. 
Un anticipo parcial de lo que sería la Constitución de Apatzingán, en el que se concretaban los ideales que habían de presidir la nueva organización política novohispana.

El Breve razonamiento que el Siervo de la Nación hace a sus conciudadanos y también a los europeos representaba el canto de cisne de Morelos, en la cumbre de su carrera y próximo ya a su declive. Sus primeras reflexiones iban dirigidas a los americanos:

(Somos libres por la gracia de Dios e independientes de la soberbia tiranía española, que con sus cortes extraordinarias y gobiernos muy extraordinarios y muy fuera de razón quieren continuar el monopolio con las continuas metamorfosis de su gobierno, concediendo la capacidad de constitución que poco antes negaba a los Americanos, definiéndolos como brutos en la sociedad). ${ }^{79}$

La confusión política de los gobiernos españoles y su apurada situación económica facilitaban el resquebrajamiento de la confianza que en ellos pudieran depositar los americanos. Por eso, la coyuntura era la más idónea para lograr la separación de la metrópoli, que se vería facilitada por la concertación de un plan que permitiera la destrucción de todas las fuentes de riqueza, a la que seguiría irremediablemente el colapso del gobierno virreinal.

Como ya se ha señalado con anterioridad, una de las razones que decidió a Morelos a convocar el Congreso fue la necesidad de poner fin a las discordias entre los miembros de la Junta, y la elaboración de un programa común que recogiera las aspiraciones de los que habían desafiado a las armas españolas. Algunos de los dirigentes de la insurgencia entendían que esa concertación pasaba por la adopción de un texto constitucional, que proporcionara un marco jurídico de referencia.

Ya en abril de 1812 Rayón había enviado a Morelos un proyecto de constitución, para que lo revisara e hiciera las oportunas observaciones. ${ }^{80}$ Se recogía en ese texto una explícita profesión

79 Ibidem. Breve razonamiento que el Siervo de la Nación hace a sus con-, ciudadanos y también a los europeos. Tlalcosautitlán, 2 de noviembre de 1813. Cuaderno $2,13$.

80 Ibídem. Rayón a Morelos. Campo de Zinacantepec, 30 de abril de 1812. Cuaderno 2, 2. 
de fe, se declaraba la religión católica como la única oficial, se encargaba la vigilancia del dogma a un tribunal de la $\mathrm{Fe}$, y se creaban cuatro órdenes militares: Guadalupe, Hidalgo, Aguila y Allende. Proclamaba la independencia de toda otra nación; reconocía el origen popular de la soberanía, que residía en Fernando VII, aunque su ejercicio en el Nuevo Mundo - por las pecurliares circunstancias de la península - correspondía el Supremo Consejo Nacional Americano; y propugnaba la separación de los tres poderes, legislativo, judicial y ejecutivo. Otras aspiraciones genuinamente liberales que se contenían en el proyecto constitucional eran la apertura de los puertos al libre comercio, abolición de los gremios y la libertad de imprenta en cuestioncs científicas y políticas, «habiéndose de respetar las legislaciones vigentes». ${ }^{81}$

En la preparación de ese proyecto no se había contado con Morelos, pues - como explicaba el propio Rayón - su nombramiento como vocal de la Junta fue posterior a la redacción de aquel borrador. Invitado, no obstante, y por segunda vez a exponer su opinión, Morelos apuntó una serie de rectificaciones al proyecto de Rayón. ${ }^{82} \mathrm{Tal}$ vez influido por esas consideraciones o por una más atenta reflexión, Rayón desistió de sus propósitos antes de que se reuniera el Congreso, que no se ocupó, por tanto, de la discusión del proyecto constitucional. ${ }^{83}$

\section{La Constitución de Apatzingán}

Maduración del proyecto de Rayón y de otros más deslavazados que le siguieron fue la Constitución de Apatzingán, elaborada por un Congreso errabundo y perseguido por las tropas virreinales que mandaba Negrete. Publicada el 22 de octubre de 1814, equivalía prácticamente a la española de 1812 y representaba la fusión

81 Ibídem. Proyecto de Constitución de Rayón. Cuaderno $2,1$.

82 Ibídem. Así, por ejemplo, con respecto al artículo 5.", que sostenia la soberanía de Fernando VII, observaba que «como es tan pública y notoria la suerte que le ha cabido a este grandísimo hombre, es necesario excluirlo para dar al público la Constitución». La contestación de Morelos se expidió en Tehuacán el 7 de noviembre de 1812. Cuaderno, 2, 2.

83 A.G.I., México, 1.483. Rayón a Morelos. Puruarán, 2 de marzo de 1813. Cuaderno 2, 5 . 
del pensamiento escolástico tradicional con las nuevas ideas liberales. ${ }^{84}$ Aunque partidarios de la república, sus redactores accedieron al establecimiento de una forma de gobierno provisional, en espera de que la nación pudiera decidir cuál habría de ser la definitiva. Sus principios y declaraciones más generales eran los habituales: soberanía de la nación, división de poderes, sistema de elecciones en tres grados de sufragio, etc.

A pesar de los inconvenientes de su redacción apresurada, introducía una forma viable de gobierno; conservaba la unidad nacional y, con un ejecutivo compuesto de tres personas, impedía que nadie pudiera arrogarse dictatorialmente la dirección de la insurgencia. ${ }^{85}$

Su publicación acrecentó las preocupaciones del virrey Calleja, por cuanto contribuía a estrechar los vínculos entre los rebeldes:

“Leíase la constitución en el mismo palacio, y no bastaron a impedir su curso ni las amenazas, ni las conminaciones, ni las excomuniones que contra ella fulminó la Inquisición de México, calificándola de herética, principalmente por la base fundamental de la soberanía del pueblo».. ${ }^{86}$

\section{Los Guadalupes y Morelos $^{87}$}

Más elocuente que cuanto podamos recoger en estas páginas acerca de la ayuda que los miembros de esta sociedad mexicana prestaron a Morelos es la continua referencia que a ellos hemos ido haciendo a propósito de las incesantes noticias que, mediante correos secretos, hacían llegar a Morelos y a otros dirigentes de la rebelión.

84 Stoetzer, O. C.: La Constitución de Cádiz..., págs. 647-648.

85 Alamán, L.: Historia de México, 5 vols. México, 1942, tomo IV, págs. 163164 y 169.

86 Bustamante, C. M. de: Cuadro Histórico..., tomo II, pág. 530.

87 Sobre los Guadalupes puede leersé Torre Villar, E. de la: Los Guadalupes y la Independencia, México, 1966, y Timmons, W. H.: Los Guadalupes: a secret society in the Mexican Revolution for Independence. «Hispanic American Historical Review», 30, 4, Durham, noviembre 1950, págs. 453-479. 
Su existencia fue conocida por Calleja que, gracias a la documentación arrebatada a los insurgentes en Puruarán y otras acciones, pudo desenmascarar a muchos de sus miembros. A ellos se refería en una carta al ministro de Gracia y Justicia, fechada en México en agosto de 1814, de la que proceden estos párrafos que, por su extraordinario interés, reproducimos en su integridad:

"Una liga facciosa que ha subsistido bajo el nombre de los Guadalupes más de tres años en el seno de esta capital y con relaciones en todo el reino, compuesta de un gran número de gentes visibles y de necesaria intervención en el gobierno, dirigía los cuerpos rebeldes sosteniéndolos y reanimándolos en sus derrotas. De este club recibían cuantas noticias podían conducir a su seguridad y acierto, remitiéndoles diarios exactos de cuanto pasaba en la capital; estados de fuerza; de municiones y caudales sacados de las mismas oficinas del Gobierno; relación de sus recursos, escaseces y apuros, y razón de cuantas resoluciones tomaba el virrey en las diferentes circunstancias que ocurrían: cuyos documentos adquiridos en las últimas considerables derrotas que ha sufrido el enemigo, han facilitado la descubierta de algunos de los muchos reos de la facción, y debían haber producido el efecto de purgar el país de los muy temibles revoltosos, desorganizar la rebelión, de imponer a los traidores ocultos y de afirmar el Gobierno, si yo hubiera podido obrar con autoridad y desembarazom. ${ }^{88}$

La formación de este grupo pudo estar relacionada con la existencia de varios núcleos comprometidos en el alzamiento de noviembre de 1810, al que trataron de apoyar de diversas formas. Después de que algunos de ellos fueran descubiertos y castigados, se volvieron más cautelosos. Sus primeras conexiones se establecieron con Rayón que, después de la captura de Hidalgo, dirigía el sector más activo de la insurgencia. Esos contactos, que se prolongaron durante todo el año 1811, contribuyeron a la mejor organización del grupo y dotaron de mayor solidez a la Junta for'mada por Rayón. Después de que en 1812 Morelos asumiera un

88 A.G.I., México, 1.482. Calleja al ministro de Gracia y Justicia, núm. 24, México, 18 de agosto de 1814. 
papel preponderante, sería éste el destinatario de la correspondencia de los Guadalupes, que no se interrumpiría hasta la muerte del Siervo de la Nación, en 1815.

Las cartas que los mantenían enlazados con los jefes eran portadas por mensajeros a quienes auxiliaba una cadena de simpatizantes, que permitía también el intercambio de libros, periódicos, armas y todo género de pertrechos. Además de las cartas, se servían de unos diarios en los que quedaba reflejado todo cuanto ocurría en la capital del virreinato. No se conformaban con suministrar estas informaciones a los jefes insurgentes sino que, interesados en propagar el pensamiento revolucionario, les proveían de imprentas en las que pudieran reproducirse decretos y proclamas. Así, hicieron posible la aparición del periódico «El Despertador Americano», que dirigió don Francisco Severo Maldonado.

Réplica de esta organización fue la red de espías tendida por el gobierno virreinal, de cuya existencia estaban informados los Guadalupes. En esta maraña de complots y espionajes recíprocos estaba enredado todo tipo de personas: figuras destacadas de la judicatura, del clero, funcionarios de la administración pública, etc.

El año 1814 resultó fatal para los Guadalupes. Las derrotas sufridas por los rebeldes, en las que se incautaron papeles comprometedores para los miembros de la sociedad, y las cartas que Calleja recibía de sus colaboradores le proporcionaron datos que le permitieron actuar. La posterior captura y muerte de Morelos tendría un efecto decisivo: las comunicaciones del grupo con los jefes rebeldes fueron haciéndose cada vez más espaciadàs, hasta terminar por extinguirse en 1816: su operatividad, sin embargo, no era ya la de antes. ${ }^{89}$

\section{Conclusiones}

Al terminar estas páginas, vale la pena poner el acento en los aspectos más sobresalientes del período que ha sido objeto de nues-

89 Torre Villar, E. de la: Los Guadalupes..., págs. XX, XXIII, XXV, XXVIIIXXX, XXXII-XXXIII, XXXV y XXXVIII. 
tro estudio. Debe destacarse, en primer lugar, la intensidad del sentimiento anti-gachupín que, robustecido por otros móviles -la defensa de los valores tradicionales o la reacción ante la traición de las autoridades metropolitanas, que habían dejado libre el campo a Napoleón - y avivado por los planes conspiratorios, puede explicar el carácter de guerra civil que atribuimos a los primeros movimientos independentistas de Nueva España: eso constituiría la clave para entender la complejidad de las actitudes y la inusitada dureza de las acciones bélicas y de la consiguiente represión. Porque el debate en curso no era estrictamente político - la con troversia era mucho más radical- el régimen constitucional se revelaría inviable para frenar la insurrección: más aún, contribuiría a su mayor difusión, a consecuencia de la vigorización de las energías locales que supusieron las nuevas disposiciones en materia municipal y de la instauración de la libertad de prensa. Pero tampoco podía llegar la solución mediante la reimplantación del Antiguo Régimen, cuyo momento histórico, por lo demás, ya había pasado.

La difícil coyuntura por la que atravesaba la metrópoli, sumida en guerra contra las tropas invasoras francesas, y la complicadísima situación económica repercutieron en beneficio de la causa insurgente, al verse privadas las autoridades virreinales de los medios indispensables para dominar la revuelta.

Sin embargo, la desgraciada coincidencia entre la publicación de la Constitución de Apatzingán -en la que se recogían las principales aspiraciones que, en el orden político, había enunciado un año antes el Congreso de Chilpancingo- con los más graves reveses militares de los insurgentes supuso un freno temporal al proceso de la independencia: esa detención pareció adquirir carácter definitivo con la captura y muerte de Morelos, alma de aquel Congreso, el silenciamiento de la prensa rebelde y la desarticulación del grupo de los Guadalupes que, durante años, había representado una eficacísima cabeza de puente entre la capital del virreinato y los principales caudillos de la insurgencia.

\section{Manuel Ferrer MuÑoz}


Nueva España en los comienzos de la lucha por la independencia

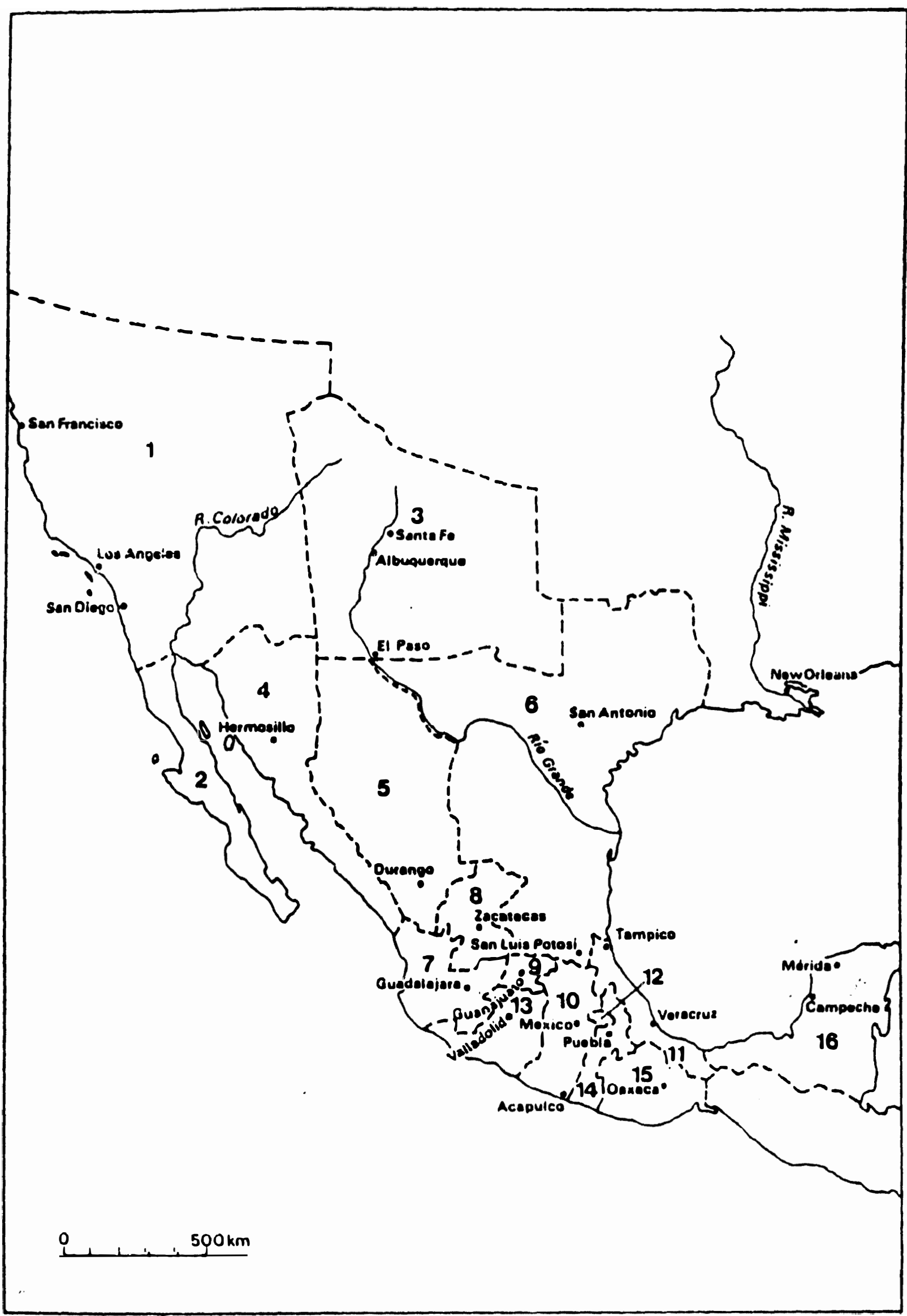

El mapa está tomado de ANNA, T. E., «The Independence of Mexico and Central America», en BETHELL, L. (ed.). The Cambridge History of Latin Ameri. can, 2 vols., Cambridge, Cambridge University Press, 1985, tomo III, págs. 51-94. 


\section{L $\Lambda$ V E :}

1. Gobierno de Nueva California.

2. Gobierno de la Vieja California.

3. Gohierno de Nuevo México (una de las Provincias Internas del (Oeste).

4. Intendencia de Arizpe (Gobierno de Sonora y Sinaloa, Provincias luternas del (este).

5. Intendencia de Durango (Gobierno de Nueva Vizcaya, una de las Provincias Internas del Oeste).

6. Intendencia de San Luis Potosí (incluye los Gobiernos de Coahuila, Texas, Nuevo León y Nuevo Santander, las Provincias Internas del Este).

7. Intendencia de Guadalajara.

8. Intendencia de Zacatecas.

9. Intendencia de Santa Fe de Guanajuato.

10. Intendencia de México.

11. Intendencia de Veracruz.

12. Gobierno de Tlaxcala.

13. Intendencia de Valladolid de Michoacán.

14. Intendencia de Puebla.

15. Intendencia de Antequera de Oaxaca.

16. Intendencia de Mérida de Yucatán. 